\title{
Si las bacterias publicaran
}

\author{
If bacteria could publish
}

$\mathrm{S}$ entado al microscopio observaba una tinción de Ziehl-Neelsen, buscando la roja faz del bacilo de Koch, cuando advertí en un campo una curiosa imagen, perfectamente rectangular, que no estaba teñida y parecía tener líneas paralelas en su interior. A fin de poder ampliarla, tomé una fotografía digital con una excelente cámara, como seguramente tienen todos los hospitales del país, y la puse en el computador, con la pantalla al $500 \%$. Imaginaos mi sorpresa al comprobar que era un texto escrito con curiosos caracteres cuneiformes. ¿Quién podría haber escrito ese documento microscópico para exponerlo a los ojos de un microbiólogo, sino alguna bacteria letrada?

Recordé que el siglo XVII el erudito monje Athanasius Kircher, el primero en ver bacterias con un imperfecto microscopio de la época, hallazgo al que, ocupado en quehaceres místicos, no dio mayor importancia, había escrito un Tratado para la comprensión de la lengua de los seres inferiores, donde explicaba cómo traducir el lenguaje de los animálculos. Con su ayuda descifré el misterioso documento, que resultó ser un poster gigante presentado al "VI Congreso Mundial de Humanología", como estaba anotado en uno de sus márgenes, donde se explicaba que "se había efectuado recientemente en un caballo muerto, en las afueras de la ciudad que los multicélula-diferenciados llaman San Jaime". En dicho poster aparecía el siguiente trabajo:

Epidemia de mujeriosis en una colonia de Listeria. Dr. Azotobacter 76-76 y Srta. Coli-coli F-. Departamento de Agresiones Humanas, Centro Nacional de Pathos, Legionella City.

Se describe una epidemia de 7 casos de mujeriosis aguda en una colonia de Listeria. Los casos presentaron una sintomatología muy similar, con una secuencia patológica idéntica.

En una primera etapa, un núcleo clonal, que varió entre 567 y 1.867 .901 bacterias, fue engullido en una forma que no pudo ser determinada. Luego de un período asintomático en que el clon se reproducía satisfactoriamente, a despecho de las miríadas de leucocitos asediantes y continuas ráfagas de $\mathrm{IgG}$, los colonos presentaban los típicos signos de intoxicación por el zumo del Velludo Odioso, nuestro enemigo natural: caída en pedazos de la pared de los jóvenes de ambos sexos, deformaciones corporales y parálisis flagelar. Luego venía la clásica impotencia sexual causada por el zumo del Streptomyces, que tan bien conocen los typhidos, y la multiplicación se interrumpía.
En una segunda etapa, un período de suprema excitación triunfaba sobre la paresia flagelar y el clon sobreviviente conseguía erradicar a la mujer. Ya en vida libre, las bacterias curadas empezaban a multiplicarse para reconstituir la colonia, hasta que uno de sus clones era nuevamente engullido por otra hembra hominida de la misma cepa, que demostró ser una Femina pregnata var conyugae, y el ciclo patológico se reiniciaba.

El último de los siete casos fue fatal. Previa a la etapa de excitación liberadora, un tóxico desconocido penetró a través de las membranas celulares, produciendo una parálisis total e irreversible de las funciones vitales, con destrucción selectiva de transposones, enredones y replicones, bloqueo del sistema transfer-ribosomal y fragmentación del cromosoma. La mortalidad fue total: ninguna Listeria sobrevivió, lo que puso natural término al brote epidémico.

La signología de los seis casos iniciales corresponde a la descrita con anterioridad, hace ya 35 millonios, por Shiga 43-Hfr y Salm Lomalinda 13 en una colonia de Fusobacterium atacada por una turba de hemophiloides. No hay, en cambio, registros en la literatura científica de casos similares al último. Creemos que el tóxico desencadenante puede ser una nueva invención de los siniestros homínidos que usan blancas cutículas vegetales sobre sus epitelios pavimentosos y portan antiparras binoculares, pero los análisis químicos y biológicos no son concluyentes en cuanto a su naturaleza. Un extracto de los cadáveres de las víctimas se probó en reos de la Cárcel de Velludos, demostrándose que una dilución 1:10 elevado a menos 20 mataba al 57\% de los Mucor celestes, pero nada pudo determinarse sobre su estructura íntima.

\section{Referencias bibliográficas}

1.- Shiga 43-Hfr, Salm Lomalinda 13. A bad day for a Fusobacterium country under attack by hemophiloides. Enteropathogen 35999801; 189: 498-512.

2.- Shiga 43-Hfr and LL 13. Topics on womeniosis. Human 35996678; 3: 45.

3.- Shiga 43-Hfr and 3355-Typhi.- Outbreak of womeniosis in a neonatorum Listeria ward. Human 35986679; 3: 92.

4.- Rhodospirillum K, El Tor 3387, Strain Pi-CDC. Una puesta al día en técnicas hominidas de agresión. Ann Mut Hum 35997922; 78: 1045. 